УДК 37.018.560

DOI: 10.37026/2520-6427-2019-100-4-69-73
Ірина ЯКИМЧУК,

завідувач відділення програмування

ВСП «Рівненський коледж Начіонального університету біоресурсів і природокористування Украӥни»

\title{
ФОРМУВАННЯ МЕДІАОСВІТНІХ КОМПЕТЕНТНОСТЕЙ У ВИКЛАДАЧІВ КОЛЕДЖУ: ТЕОРЕТИЧНИЙ АСПЕКТ
}

\begin{abstract}
У статті здійснено теоретичний аналіз формування медіаосвітніх компетентностей у викладачів коледжу. Обгрунтовано, щз підготовка викладачів до застосування мас-медіа в педагогічній діяльності є одним із важливих напрямів їх фахової підготовки. Визначено необхідні умови формування медіакомпетентності викладача закладу вишої освіти. Виокремлено фактори, шо сприяють інтенсифікаиіі та якості освітнього процесу у ЗВО. Представлено етапи реалізаиї медіаосвіти відповідно до Концепиії впровадження медіаосвіти в Украӥні. Запропоновано форми і методи формування медіакомпетентностей, шуо підвищують рівень викладання навчального матеріалу педагогічними та науково-педагогічними працівниками навчального закладу.
\end{abstract}

Ключові слова: медіаосвіта, медіакомпетентність, медіаосвітні технології, медіакомпоненти.

В статье осуществлен теоретический анализ формирования медиаобразовательных компетеничии у преподавателей колледжа. Обосновано, что подготовка преподавателей к применению масс-медиа в педагогической деятельности является одним из важных направлений их профессиональной подготовки. Определены необходимые условия формирования медиакомпетентности преподавателя выстего учебного заведения. Выделень факторы, способствуюшие интенсификачии и качеству образовательного проиесса в вузе. Представлены этапь реализаиии медиаобразования в соответствии с Кониепцией внедрения медиаобразования в Украине. Предложень формы и методы формирования медиакомпетентностей, повышающие уровень преподавания учебного материала педагогическими и научно-педагогическими работниками учебного заведения.

Ключевые слова: медиаобразование, медиакомпетентность, медиаобразовательные технологии, медиакомпоненты.

The article gives a theoretical analysis of the formation of the college teachers' media education competences. It is stressed that modern computer technologies, combined with educational media technologies, become an effective means of training and self-development for future professionals. It is substantiated that the preparation of teachers for the use of mass media in pedagogical activity is one of the important areas in their professional training. It is determined the necessary conditions for forming the media competence of a teacher of a higher educational institution. It is stated that the formation of media competence of future teachers in the higher pedagogical education system can be realized if structure and content of training meet the requirements of current trends in the development of computer science and ICT in education, selection of content and forms of training according to the types of information activity of the teacher of each specialty, as well as orientation of educational and cognitive activity on the development of professional educational activity of the future teacher in this aspect of methodical work. The factors that contribute to the intensification and quality of the educational process in higher education are highlighted. The stages of realization of media education in accordance with the Concept of introduction of media education in Ukraine are presented. The Concept is based on studying the state of media culture of the population of Ukraine so as the international experience in the organization of media education and it aims at the preparation and providing stage-by-stage experimental then intensive widespread introduction of media education, in particular, into pedagogical practice at all levels. It is offered the forms and methods of formation the media competences that increase the level of teaching educational material by pedagogical and scientific-pedagogical employees of educational institution. It is identified the means of media education, in particular, traditional and newest ones, as well as forms of media education implementation.

Key words: media education, media competence, media education technologies, media components.

Постановка проблеми. Сучасний здобувач освіти (у майбутньому - фахівець у певній галузі) потребує такого навчання, яке б забезпечувало розвиток творчого мислення, самостійності й активності в навчальній діяльності, уміння набувати нові для себе знання. Таким креативним, сучасним, з уміннями й навичками володіння інформаційно-комунікаційними технологіями та використання медіаосвітніх технологій і засобів має бути й викладач. Особливо важливим $є$ те, що сучасні комп'ютерні технології в поєднанні 3 освітніми медіатехнологіями стають ефективними засобами навчання та саморозвитку майбутніх фахівців. 
Аналіз наукових досліджень і публікацій. Проблемам розробки технологій навчання приділяється належна увага в працях вітчизняних та зарубіжних дослідників. Зокрема, розглядаються такі іiї аспекти, як проєктна технологія (К. Баханов, І. Бім, В. Гуз$\epsilon є в$, I. Єрмаков, І. Зимня, Р. Курбатов, О. Онопрієнко, Н. Пахомова, О. Полат, Т. Сахарова, Г. Селевко, Н. Тарасова, С. Шевцова), теорія і практика використання інформаційно-комунікаційних технологій у педагогічному процесі (Р. Вільямс, Б. Гершунський, К. Маклін, Ю. Машбиць, С. Пейперт, О. Полат), особливості впровадження у навчальний процес мультимедійних технологій (Р. Гуревич, Ю. Батурін, М. Жалдак, В. Биков, О. Пометун) тощо.

Теорія і практика медіаосвіти в сучасному науковому дискурсі $є$ предметом дослідження значної кількості вчених, наприклад, у працях про мас-медіа загалом розглядаються моделі й методи медіаосвіти такими авторами, як Д. Бекінгем, Л. Зазнобіна, Д. Консидайн, Л. Мастерман, С. Пензін, Ю. Усов, О. Федоров, О. Шаріков, Е. Харт, Р. Хобс та ін.; психолого-педагогічними дослідженнями 3 означеного питання займалися Л. Баженова, О. Баранов, О. Бондаренко, К. Ворсноп, Н. Габор, Л. Зазнобіна, Р. Куін, О. Спічкін, О. Федоров, О. Шаріков та ін.
Проблеми використання матеріалів засобів масової інформації та їх вплив на особистість і суспільство відображено в роботах Л. Мастерман, С. Міллера, Л. Найдьонової, Б. Потятинник, Г. Онкович, Н. Саєнко, О. Сербенської, О. Тягло, О. Федорова, I. Чемерис, О. Янишин та ін.

Мета статті - здійснити теоретичний аналіз процесу формування медіаосвітніх компетентностей у викладачів коледжу.

Виклад основного матеріалу. Широкий простір Інтернету дозволяє сучасній людині отримувати необхідну інформацію, не виходячи 3 дому. Але обмежувати поповнення інформаційного запасу лише засобами інтернет-простору нераціонально. Для розширення такого запасу інформаційне суспільство використовує медіа: книги, періодику, телебачення, пошту, телефон тощо.

Медіаосвіта - це не лише шлях до ефективності діяльності людини в системі трудових відносин, а й спосіб залишатися самим собою, тобто цілісною особистістю, здатною до самовираження і людяності. Не втрачають значення і традиційні завдання медіаосвіти, які полягають у запобіганні вразливості людини до медіаманіпуляцій і медіанасильства, «втечі» від реальності, профілактиці поширення медіазалежностей (див. рис. 1).

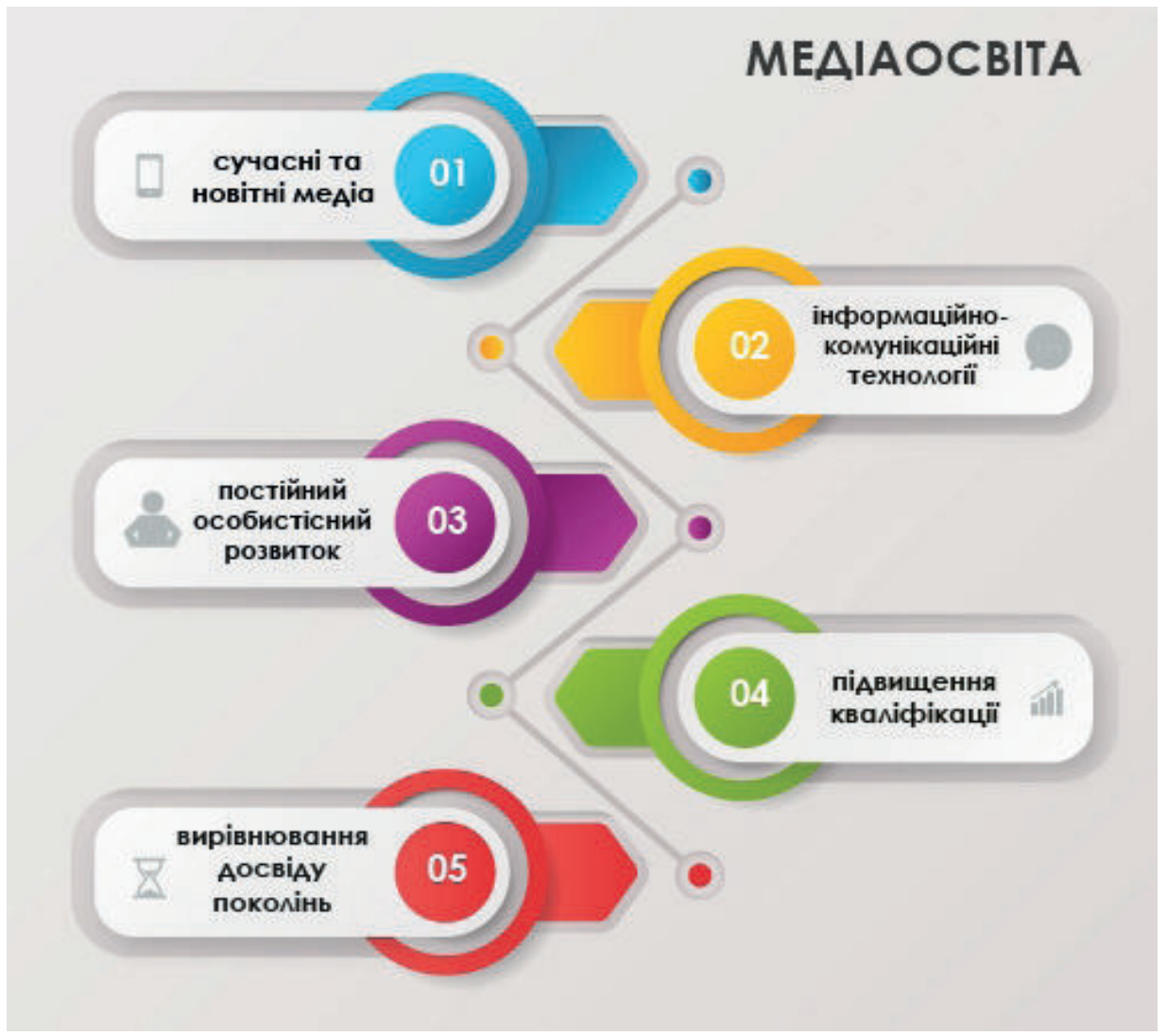

Рис. 1. Складові медіаосвіти (авторський)

Зростання ролі засобів масової інформації в освітніх процесах і складність реального їх використання, а також зміна «дидактичного ландшафту», в умовах якого має здійснюватися підготовка здобувачів освіти до життя в інформатизованому суспільстві, вимагають визначення змісту медіаосвіти викладача, без набуття якої неможливо розв'язати дане соціальне замовлення.
Вивчення нормативних документів, а також наукових публікацій [2] дало підстави для висновку, що медіаосвіта педагогічних кадрів $є$ проблемою державного рівня, а завдання підготовки висококваліфікованих кадрів, що володіють необхідним рівнем медіакомпетентності, актуальне на всіх рівнях державної системи освіти та для всіх фахівців. 
Підготовка викладачів до застосування мас-медіа в педагогічній діяльності, будучи одним із важливих напрямів їх фахової підготовки, грунтується на спеціальних знаннях і вміннях, зміст яких пов'язаний 3 основними базовими поняттями медіадидактики (мас-медіа, медіазасоби, медіаосвіта, медіасередовище, медіаграмотність, медіакомпетентність особистості, медіакомпетентність педагога, методи, форми та методика медіаосвіти) і орієнтований на показники готовності викладача та здобувача освіти до роботи з мас-медіа. Ураховуючи те, що показником готовності фахівця будь-якої професії до виконання певного виду діяльності сьогодні визнано компетентність, характеристикою медіаграмотності викладача вважатимемо його медіакомпетентність, яку будемо розуміти як інтегровану характеристику особистості, що грунтується на сукупності мотивів, знань, умінь, цінностей і здатностей, котрі спроможні забезпечити медіаосвіту здобувачів освіти різного віку [6].

Аналіз досвіду підготовки й підвищення кваліфікації педагогічних кадрів у галузі мас-медіа та інформаційних і комунікаційних технологій дозволив констатувати, що: 1) необхідними умовами формування медіакомпетентності викладача $€$ наявність фундаментальної підготовки 3 інформатики, без якої неможлива експлуатація засобів ІКТ і реалізація їх потенціалу в освітніх цілях, а також знань із психолого-педагогічних наук, засвоєння яких необхідне для ефективного здійснення всіх функцій, пов'язаних із використанням засобів мас-медіа в навчальному процесі; 2) формування медіакомпетентності майбутніх викладачів у системі вищої педагогічної освіти може бути забезпечене за умови відповідності структури й змісту їх підготовки сучасним тенденціям розвитку інформатики й IКТ в освіті, відбору змісту і форм навчання відповідно до видів інформаційної діяльності викладача кожного фаху, а також орієнтації навчально-пізнавальної діяльності на розвиток професійної освітньої активності майбутнього педагога в даному аспекті методичної роботи; 3) в умовах недостатньої готовності викладачів до впровадження мас-медіа в освітній процес до завдань підвищення їх кваліфікації мають увійти такі, що пов'язані з формуванням власної медіаграмотності та медіаграмотності студентів.

21 квітня 2016 року Президія Національної академії педагогічних наук України схвалила нову редакцію Концепції впровадження медіаосвіти в Україні. Означена концепція базується на вивченні стану медіакультури населення України та міжнародному досвіді організації медіаосвіти. Вона спрямована на підготовку i проведення широкомасштабного поетапного експериментального та подальшого інтенсивного масового впровадження медіаосвіти, зокрема й у педагогічну практику на всіх рівнях (див. рис. 2).

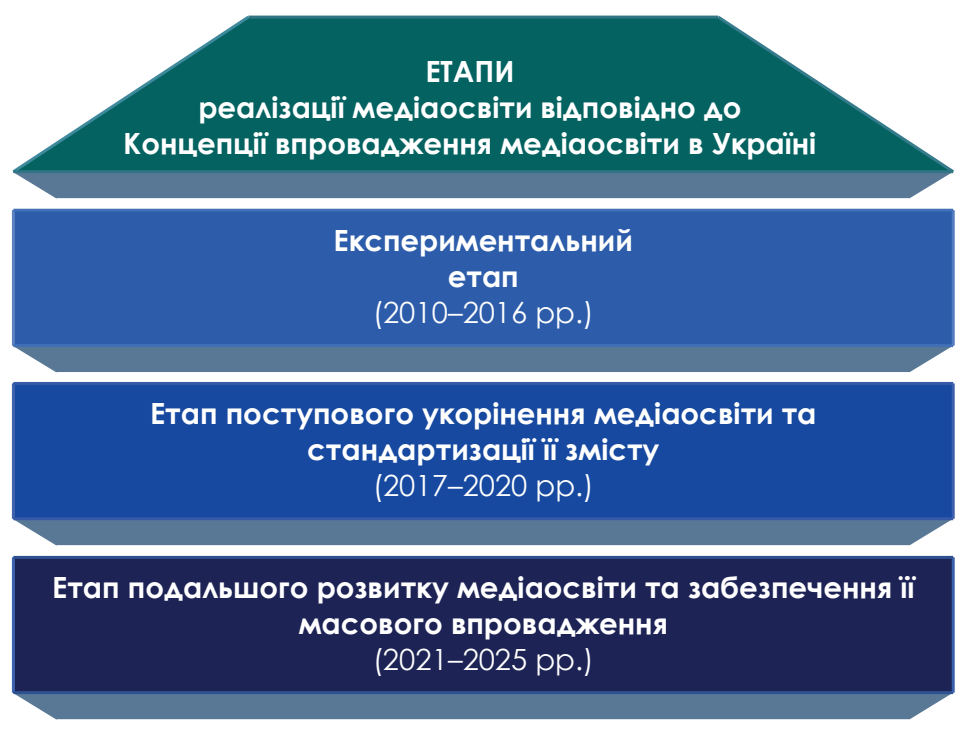

Рис. 2. Етапи реалізації медіаосвіти

відповідно до Кониеепиії впровадження медіаосвіти в Україні (авторський)

Згідно з Концепцією впровадження медіаосвіти знаходиться на етапі поступового укорінення медіаосвіти та стандартизації іiі змісту. Зважаючи на це, сьогодні питання медіаосвіти є досить актуальним. Однак варто зазначити, що медіа здійснює й негативний вплив, наслідками якого є медіаманіпуляція, медіанасильство, втеча від реальності та медіазалежність.

Результатом медіаосвіти є медіаграмотність, медіаінформаційна грамотність, медіакультура i, як найвищий ступінь, - медіакомпетентність.

Формуючи медіаграмотність і медікомпетентність не лише здобувачів освіти, а й викладачів, необхідно пам'ятати, що світ медіа постійно змінюється, однак критичне сприйняття медіамеседжів (медіапродуктів) як і раніше залишається необхідною навичкою сучасної людини і має відповідати п'яти принципам, які сьогодні лишаються актуальними та фундаментальними для системи медіаосвіти: 1) усі медіапродукти створили конкретні люди з певною метою; 2) наші уявлення про реальність грунтуються на медіа; 3) сприйняття медіапродуктів залежить від особистих потреб; 4) медіа кількох власників - це бізнес; 5) медіамеседжі (медіапродукти) рекламують ідеологію, цінності і стиль життя та зазвичай підтримують наявну систему.

Означених вище якостей можна набути під час реалізації медіаосвіти з використанням певних форм і засобів (див. рис. 3). 


\section{ЗАСОБИ I ФОРМИ РЕААІЗАЦІЇ МЕАІАОСВІТИ}
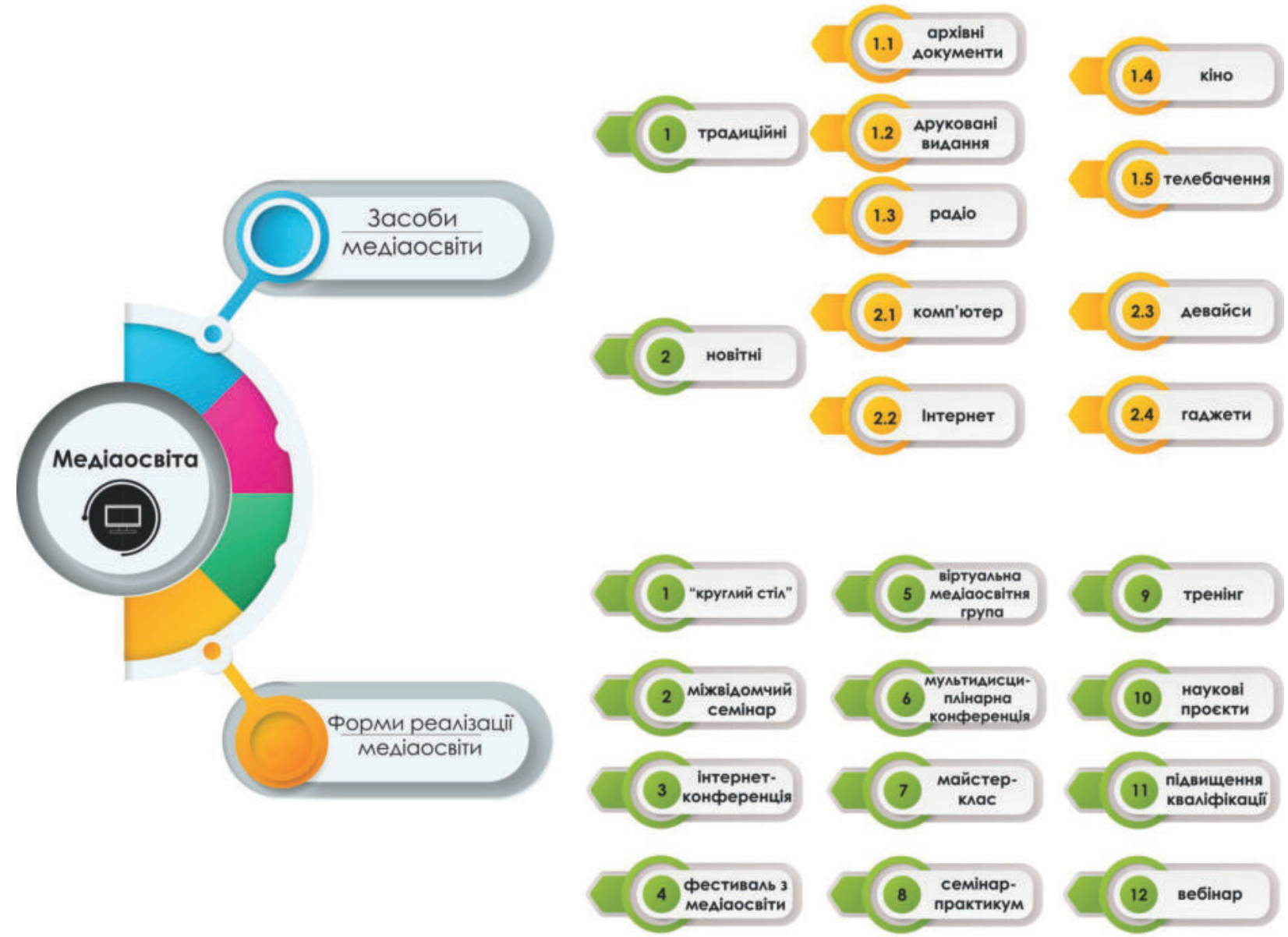

Рис. 3. Засоби і форми реалізаиї̈ медіаосвіти (авторський)

Саме майстер-класи, семінари-практикуми, «круглі столи», інтернет-конференції, тренінги тощо дають змогу викладачам і здобувачам освіти набути медіакомпетентностей.

На сьогодні кожен викладач повинен володіти медіаосвітніми компетентностями, аби якісно підготуватися до заняття. У процесі підготовки до проведення заняття викладачі переглядають новини 3 певної галузі в періодичних виданнях чи Інтернеті; вивчають законодавчо-нормативну базу та зміни, які в ній відбуваються; відшуковують відеосюжети, які наочно демонструють той чи інший процес; готують мультимедійну презентацію чи відеолекцію.

Зростання потреби в інформації та збільшення іiі потоків у людській діяльності зумовлює виникнення нових технологій - розробку і використання електронних засобів для роботи з інформацією. Нові інформаційні технології, якими є глобальна комп'ютерна мережа Інтернет, мультимедійні комп'ютерні системи, IP-телефонія, цифрове, супутникове і кабельне телебачення тощо, зумовили радикальні зрушення у всіх сегментах соціальної взаємодії.

Концептуальні підходи до формування медіаграмотності здобувачів освіти пов'язані з використанням в освітньому процесі засобів IКТ.
Яскравим прикладом того, що всі проведені заходи 3 підвищення грамотності викладачів мають результат, $€$ підготовка робіт на конкурс «Педагогічні інновації», за підсумками якого у 2018 році 28 робіт оцінені найвищим балом, а 10 - посіли призові місця. Таким чином, це доводить набуття викладачами навичок медіаосвітніх компетентностей.

Характерною ознакою освітнього процесу в коледжі $є$ поєднання традицій, досвіду, інновацій та матеріально-технічної бази. Мультимедійні засоби виконують роль наукового дослідника й одержувача інформації. До таких програмних засобів навчального призначення належать хмарні технології, що забезпечують зберігання та утримання інформаційних файлів у «хмарі», доступ до якої надає викладач. Така «хмара» наявна в кожного викладача відділення коледжу.

Керування процесом відповідно здійснює викладач або розробник шляхом подання інформації. Крім того, використовуються інтерактивні освітні засоби мультимедіа, що передбачають активну участь здобувача освіти, який може самостійно обирати шлях дослідження певної теми, визначати послідовність вивчення тощо. Роль «хмари», через яку реалізуються активні методи навчальної діяльності, відіграють мультимедійні методичні вказівки (електронні довідники, 
тренажери), гіпертекстові мультимедійні засоби, засоби і компоненти створення мультимедіа, мультимедійні засоби подання навчальних матеріалів (електронні енциклопедії, електронні посібники) [4].

Проблема доцільного й педагогічно виваженого використання хмарних технологій у закладах вищої освіти набуває всеукраїнського масштабу, а його метою є подолання освітньої нерівності та забезпечення найвищого стандарту освіти в кожному куточку України завдяки створенню єдиного навчально-інформаційного онлайн-простору для викладачів та здобувачів освіти.

У нових умовах надання освітніх послуг виникла потреба розвитку наукового мислення здобувача освіти, формування його пошукових умінь та практичної підготовки до активної життєдіяльності в соціальному середовищі. Зважаючи на це, в освітньому процесі необхідно широко застосовувати інновації.

Система хмарних технологій навчання фахових дисципліни складається із загальнонавчальних хмарних технологій (технології онлайн-розробки та онлайн-сховищ електронних навчальних матеріалів, технології управління навчанням) та вузькоспеціалізованих хмарних технологій (браузерні системи програмування й моделювання (на підтримку вивчення комп'ютерних дисциплін), мобільні бухгалтерські системи (на підтримку вивчення економічних дисциплін), віртуальні онлайн-лабораторії та системи моделювання) [3].

Новими методами і формами навчання є застосування інформаційних та комунікаційних технологій у підготовці методичного забезпечення, проведення різних типів занять, зокрема застосування в лабораторіях комп'ютерної техніки та прикладного програмного забезпечення, яке $\epsilon$ специфічним для використання здобувачами освіти різних спеціальностей.

Основними формами підвищення ефективності навчального процесу в коледжі є: інформаційно-масові (дискусії, конференції, інтелектуальні аукціони, «філософський стіл», ринги, створення книг, газет); діяльнісно-практичні, групові (творчі групи, клуби, ігри-драматизації, олімпіади); інтегративні («круглий стіл»); діалогічні (бесіда, міжрольове спілкування); індивідуальні (доручення, творчі завдання, звіти). Варто також наголосити на популярності в закладі таких заходів, які час від часу проводяться завдяки сайтам відділення шляхом викладу матеріалів або їх обговорення через соціальні мережі.

Виконання практичних чи лабораторних робіт вимагає від здобувача освіти пошуково-дослідницького підходу, творчої ініціативи, самостійності у прийнятті рішень, глибокого знання і розуміння навчального матеріалу. Аби допомогти здобувачам освіти в цьому, викладачами розроблено електронні версії посібників, що дають змогу працювати в електронній бібліотеці, яка розміщена у «хмарі» бібліотечно-інформаційного центру коледжу та на сайті відділення.

Окремими видами індивідуальних завдань навчально-дослідного, творчого чи проєктно-конструк- торського характеру $є$ курсова робота, виробнича практика, дипломне проєктування. Усі представлені види робіт супроводжуються консультаціями викладача шляхом надання методичних рекомендацій. Методичні рекомендації щодо виконання дослідної роботи зберігаються у «хмарі» викладача у вигляді посібника та в електронному форматі на сайті відділення. Також студенти в разі потреби можуть звернутися за консультацією до викладачів, які є керівниками наукової роботи. Консультування відбувається як на заняттях під час виконання лабораторної роботи, так і через e-mail або Skype викладача.

Висновки. Таким чином, можливість застосування медіаосвітніх технологій в освітній діяльності коледжу визначається наявністю сучасної матеріально-технічної бази та програмного забезпечення, готовністю науково-педагогічних працівників до оволодіння навичками й уміннями застосування медіатехнологій та їх використання у навчальному процесі, а також мотиваційною установкою формування професійної компетентності майбутнього фахівця.

\section{СПИСОК ВИКОРИСТАНОЇ ЛІТЕРАТУРИ}

1. Гриб'юк О. О. Перспективи впровадження хмарних технологій в освіті / О. О. Гриб'юк. URL: http://ib.iitta.gov.ua/1111/ (дата звернення: 10.09.2019).

2. Європейські критерії медіаграмотності (фрагмент із програми Л. А. Найдьонова «Медіапсихологія: основи рефлексивного підходу») на основі «Media Literacy Study The Framework». URL: http://ec.europa. eu/culture/media/literacy/docs/studies/eavi_annex b framework_rev_en.pdf (дата звернення: 11.09.2019).

3. Литвинова С. Хмарно орієнтовані технології в сучасній освіті / С. Литвинова. URL: http://virtikt. blogspot.com (дата звернення: 10.09.2019).

4. Марковська О. С. Сучасні чинники формування професійно-практичних умінь і навичок майбутніх інженерів-педагогів машинобудівного профілю / O. Є. Марковська. URL: http://repository.kpi.kharkov.ua/ handle/KhPIPress/13628 (дата звернення: 11.09.2019).

5. Миколаєнко А. Є. Сутність формування засобами медіаосвіти технологічних понять в учнів професійно-технічного навчального закладу / А. С. Миколаєнко // Наукові записки. - 2013. - № 3. С. 147-151. - (Серія «Педагогіка»).

6. Роберт I. В. Толкование слов и словосочетаний понятийного аппарата информатизации образования / I. В. Роберт // Информатика и образование. - 2004. № 6. - С. 63-70.

7. Саварин П. В. Підготовка майбутнього викладача технічних дисциплін до застосування медіатехнологій у професійній діяльності : автореф. дис. на здобуття наук. ступеня канд. пед. наук : спец. 13.00.04 / П. В. Саварин ; Східноєвропейський націон. ун-т ім. Л. Українки. - Луцьк, 2017. - 18 с.

Дата надходження до редакиї: 16.09.2019 р. 